\title{
INDIGENCE OF FORENSIC ODONTOLOGY IN LEGAL PRACTICE OF PAKISTAN
}

\author{
Hashim Bin Mansoor, Usman Zafar Kayani, Reeja Khatoon*, Erum Idrees, Hira Zafar Kayani*, Ayesha Aslam \\ Armed Forces Institute of Dentistry/National University of Medical Sciences (NUMS) Rawalpindi Pakistan, *Margala Dental College, Rawalpindi Pakistan
}

\section{ABSTRACT}

Objective: To assess and interpret the utility and need of forensic dentistry in current judicial system of Pakistan. Study Design: Cross sectional study.

Place and Duration of Study: Twin cities of Rawalpindi and Islamabad, in the month of Jun, 2020.

Methodology: This questionnaire based cross-sectional study was conducted in a 1-month time frame, and a sample of 100 lawyers was recruited using snowball sampling technique and only criminal lawyers were included which had a minimum of 5 years of experience. Data was analyzed using SPSS-24.

Results: The results were quite significant, $81 \%$ (81 lawyers) of the population recognized the relationship of forensic dentistry with criminal litigation ( $p$-value $=0.006$ ). Furthermore $86 \%$ (86 lawyers) believed that there are a limited number of practicing forensic dentists and a massive $96 \%$ (96 lawyers) of the population was not able to acquire the expertise of a forensic dentist.

Conclusion: There is a major lack of trained forensic odontologists and training institutes in Pakistan, which has a significant effect on the legal practices of Pakistan. Furthermore, it defines the lack of specialization trend in forensic odontology.

Keywords: Criminal lawyers, Dentistry, Forensic dentists.

How to Cite This Article: Mansoor HB, Kayani UZ, Khatoon R, Idrees E, Kayani HZ, Aslam A. Indigence of Forensic Odontology in Legal Practice of Pakistan. Pak Armed Forces Med J 2021; 71(5): 1709-1712. ～doi: https://doi.org/10.51253/pafmj.v71i5.5044

This is an Open Access article distributed under the terms of the Creative Commons Attribution License (https://creativecommons.org/licenses/by-nc/4.0/), which permits unrestricted use, distribution, and reproduction in any medium, provided the original work is properly cited.

\section{INTRODUCTION}

Forensic odontology has been described as "a branch of dentistry that in the interest of justice, deals with the proper handling and examination of dental evidence; along with evaluation and presentation of dental findings" ${ }^{1}$

Forensic dentistry owing to its significance in the modern world is a variant of forensic medicine that aids in provision of justice, examination of data and dental evidence under the law. ${ }^{2}$ Tooth being the hardest tissue in the human body is impervious to decay under extreme circumstances of accidents, crime scenes or explosions. Every individual has his/her own peculiar dental pattern in a lifetime; hence, this pattern can assist in the identification of one's remains and comparison. ${ }^{3}$

Forensic dentistry being multidisciplinary laid the basis of dental evidence, bite mark evidence, miscellaneous pattern markings, DNA fingerprinting, human abuse evidence and developmental analysis i.e. rugoscopy and cheiloscopy in order to resolve the issues related to civil cases, criminal cases and dental jurisprudence. ${ }^{4}$ Despite being a well-established area in dentistry, its practical application in the legal

Correspondence: Dr Hashim Bin Mansoor, Department of Dentistry, Armed Forces Institute of Dentistry, Rawalpindi Pakistan

Received: 18 Aug 2020; revision received: 15 Oct 2020; accepted: 16 Oct 2020 system is under the authority of legal professionals and their interaction with forensic odontologists in legal issues. ${ }^{5}$

Even though forensic dentistry is a worldwide known, reliable and accepted medium in regard to solving criminal or civil proceedings under court or legal agencies, its integration in Pakistani law and legal system is null. The course has never been taught widely in country at undergraduate or postgraduate levels. A very few of the forensic specialists are available in our country, that too are home returned from foreign countries.

Higher Education Commission of Pakistan (HEC) is the regulatory authority of undergraduate and postgraduate curriculums in Pakistan. According to its approved curriculum for Bachelor of Dental Surgery (BDS), there is no theoretical nor practical component regarding forensic dentistry at undergraduate or postgraduate level. ${ }^{6}$

Over last few decades, forensic medicine and forensic dentistry based programs have attained a very high status in many developed countries such as Norway, Belgium, Australia, United Kingdom and United States of America. As a result, even developing countries such as India via its regulatory body i.e. Dental Council of India has included a thirty hour taught program of forensic dentistry in the four-year program of BDS degree. ${ }^{7}$ 
Pakistan in the last decade has seen an increase in cases related to murder, rape, assaults and molestation. Added to this, both natural and unnatural disasters such as earthquakes and suicide bombings, plane crashes and mass shootings respectively have aggrandized. A recent statistic regarding the murder rate in Pakistan at 6.8 (in a 100,000 population) as compared to India at 2.8 is alarming in itself. ${ }^{8}$ Furthermore Pakistan stands at number 16 in the world in terms of crime levels. ${ }^{9}$ Most litigation in cases that fall under the category of violent crimes, depend on permissible forensic evidence.

In order to meet the future challenges in criminal justice system and police agencies, introduction of forensic dentistry as a taught program both at undergraduate and postgraduate level in Pakistan is crucial. Also, an increase in number of specialists in this field is critical as recently there are only just two known specialists working in Pakistan as compared to 86 diplomats of the American Board of Forensic Dentistry.

The research rationale was to identify the utility and accessibility of forensic dentists in our judicial system in particular. Furthermore, it will evaluate the current status of aide provided by forensic dentists in litigation and will be a guide for further research work on this topic.

\section{METHODOLOGY}

A cross-sectional study was conducted over a period of 1 month from June to June in Rawalpindi/ Islamabad. Hypothesized frequency of outcome factor in the population(p): $85 \% \pm 5$, at Confidence Level $(95 \%)$ using Equation Sample Size $\mathrm{n}=\left[\mathrm{DEFF}^{*} \mathrm{~N} p(1-\right.$ $p)] /\left[\left(\mathrm{d} 2 / \mathrm{Z} 21-\mathrm{a} / 2^{*}(\mathrm{~N}-1)+p^{*}(1-p)\right]\right.$ from Open Epi, Version 3, open source calculator SSPropor. A sample size of 100 participants was calculated. Non-probability consecutive sampling method was employed.

Inclusion Criteria: Lawyers who were currently practicing criminal law and had at least 5 years' experience in criminal litigation.

Exclusion Criteria: Non-consenting lawyers were excluded.

Data was collected in a personalized manner by means of a properly designed structured questionnaire. The questions asked were framed to assess the need of forensic dentists in the local judicial system, for crim-inal case proceedings by lawyers already practicing criminal law.

A structured questionnaire was designed, face validated and filled in a face to face interview with every lawyer. Informed consent of the participant was taken before filling the questionnaire. The questionnaire was divided into three components, in which first section was focused on demographic profile (demographic distinctiveness limited to gender only) of the study population, the second section was based on basic information regarding forensic dentistry and the third section was for the specific assessment of the population's own experience regarding availability and abundance of forensic dentist aide.

Data was analyzed using SPSS-24. Descriptive statistics were calculated. Chi-square test was used for effect modifiers such as gender. The $p$-value $\leq 0.05$ was considered significant.

\section{RESULTS}

Amongst the 100 practicing criminal lawyers, 62 lawyers were male and 38 lawyers were females. Eighy one lawyers stated that they believe a strong association of forensic dentistry with litigation existed, irrespective of the gender of the subjects. Eighy six lawyers were of the opinion that there are not abundant forensic dentists in Pakistan. Ninety six lawyers found themselves to be incapacitated to find a forensic dentist in their locality. Male and female respondents did not differ statistically in terms of their opinion regarding requirement of a forensic dentist's intervention in trial proceedings $(p=0.89)$ as depicted in Table.

Table: Lawyers that required forensic dentist during their career

\begin{tabular}{l|c|c|c}
\hline & \multicolumn{2}{|c|}{ Have you ever required a Forensic Dentist } & \multirow{2}{p}{$\begin{array}{c}\boldsymbol{v} \\
\text { value }\end{array}$} \\
\cline { 2 - 3 } & Required & Did not Require & 0.89 \\
\hline Males & $40(39.68)$ & $22(22.32)$ & \\
\hline Females & $24(24.32)$ & $14(13.68)$ & \\
\hline
\end{tabular}

This relationship cannot be overstated since it shows a huge amount of lawyer population that had no access to a forensic dentist due to extreme paucity. Ninety lawyer expedites the court proceedings while 10 lawyers did not really affect court proceedings (Figure).

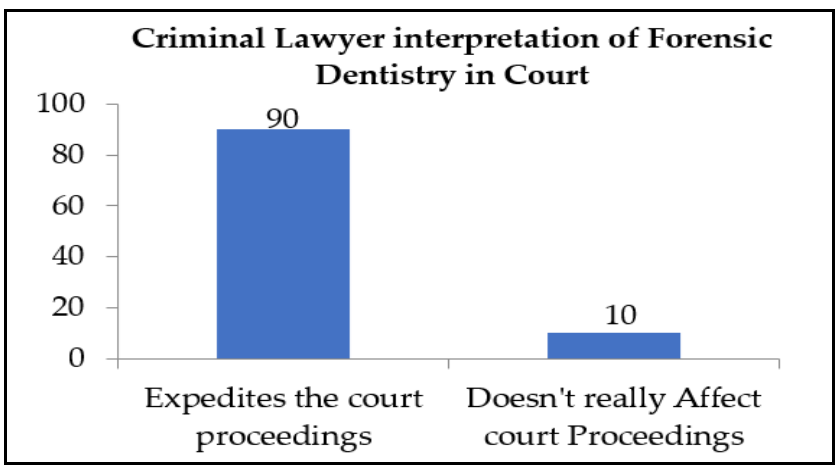

Figure: Legal practitioners' assessment of effect of forensic dentistry in proceedings. 


\section{DISCUSSION}

The glorious past of medicine was highlighted by an ever-increasing wealth of knowledge, which was lately joined by the field of dentistry and it showed a rapid transition from orthodox dental practices to the modern era of dentistry that we see nowadays. Healthcare studies that deal with dead i.e. forensics had shown a dramatic rise in research work which lead to discovery of a number of deadly diseases such as chronic traumatic encephalitis. ${ }^{10}$ Moreover, forensics is the part and parcel of the litigation procedures throughout the world. However, in this regard forensic odontology specifically hasn't received its due share of importance.

The horizon of forensic dentistry broadly covers three areas, namely, (1) human remains' identification, (2) litigation relating to malpractice, and (3) criminal proceedings, primarily in the areas of bitemark evaluation and child abuse ${ }^{11}$. In a country like Pakistan much of these matters are dealt with basic clinical experience of general dentists or forensic medicine experts, but the deserved importance of a forensic dentist is far from being a reality. It is further superimposed by the fact that the study at hand is the first ever assessment of need of a forensic dentist in Pakistani system of justice.

Le Moyne Snyder was the first person to suggest the use of lip prints for identification of an individual in the year 1950.12 Furthermore, between 2000 and 2012 two studies were carried out by researchers which related to lip prints and their use in forensic odontology. ${ }^{13,14}$ These studies depict the importance of intervention of forensic dentistry in medicolegal system of a country that Pakistan unfortunately lacks. Cheiloscopy for instance is the paramount investigative technique that is to be used in litigation of child abuse and harassment suspects, but its awareness in legal system of Pakistan is currently negligible.

A study done in Dow University of Health Sciences states that $84 \%$ of the dentists had no knowledge of forensic dentistry and $87 \%$ of them agreed to the significance of forensic odontology to the legal system by identification of crime suspects. ${ }^{15}$ Dentists who play a part in identification of the deceased individual or in a criminal investigation are then required to present their findings in the court of law as an 'expert witness". ${ }^{16}$ According to a study done in Karachi, more than half of the dental practitioners are aware of the fact that they can appear in front of court as expert witnesses for forensic dentistry related evidence but also accept the fact regarding paucity and extreme scarcity of forensic odontologists in a matter of life and death of a criminal in Pakistani litigation system. 17 But none of the studies mention any aspect regarding point of view of legal practitioners whereas the current study specifically addresses the concerns and insight of law practitioners of Pakistan.

Child sexual abuse, which was previously a hidden phenomenon and its reporting and legal action against it was considered a cultural taboo for most of the population, is currently being taken very seriously and the issue is raised internationally at an rapid rate. Legal action against such maniacs can best and most effectively be brought forward by skills of a forensic odontologists i.e. salivary analysis, cheiloscopy, analysis of bite marks etc ${ }^{18}$. thereby, endorsing the importance of forensic dentistry in litigation system of a country.

The $21^{\text {st }}$ century has brought pleasing things in our lives like a booming information technology (IT) industry and marvelous healthcare methods. It has also brought new calami-ties of terrorism and industrial disasters and increased crime rate. Oral hard tissues are resistant to exposure to extreme conditions and are usually the only remains even after a considerable time after burial ${ }^{19}$. These dental tissues can be used for recognition of the bodies as well as other judicial proceedings ${ }^{20}$.

The study is the first of its kind that involves the opinion of legal practitioners regarding their need of a neglected subject in dentistry. More studies on this aspect may pave the way for a revolutionary change in the curriculum of dental colleges in Pakistan. The short duration of study and small sample size are the limitations of the study at hand.

\section{CONCLUSION}

According to the members of legal system of the country, there is a major lack of trained forensic odontologists and training institutes in Pakistan, and has a significant effect on the legal practices of the country. This study may represent the current status of dental practitioners in the field of forensic odontology.

\section{Conflict of Interest: None.}

\section{Authors' Contribution}

HBM: Direct contribution, writing, data analyis, UZK: Data analysis, RK: Data interpretation, EI: Data editing, HZK: Proof reading, AA: Statistical analysis.

\section{REFERENCES}

1. Keiser-Nielsen S. Person identification by means of the teeth: a practical guide. Wright 1980, [Internet] Available at: https:// 


\section{Forensic Odontology}

www.worldcat.org/title/ person-identification-by-means-ofthe-teeth-a-practical-guide/oclc/6813484

2. Krishan K, Kanchan T, Garg AK. Dental evidence in forensic identification - an overview, methodology and present status. Open Dent J 2015; 9(2): 250-256.

3. Auerkari E. Recent trends in dental forensics. Indonesian J Legal Forensic Sci 2008; 1(1): 282217.

4. Saxena S, Sharma P, Gupta N. Experimental studies of forensic odontology to aid in the identification process. J Forensic Dent Sci 2010; 2(2): 69-76.

5. Preethi S, Einstein A. Awareness of forensic odontology among dental practitioners in Chennai: A knowledge, attitude, practice study. J Forensic Dent Sci 2011; 3(2): 63-66.

6. Curriculum of bachelor of dental surgery (bds) five years Programme. 2011, [Internet] Available at: https://hec.gov.pk/ english/services/universities/RevisedCurricula/Documents/2 010-2011/Draft-BDS-2011.pdf (Accessed on July 10, 2020)

7. Syllabus for Undergraduate (BDS) (Screening Test For Indian Nationals With Foreign Dental Qualifications). 2011, [Internet] Available at: https://www.amu.ac.in/newdata/course/10480. pdf. (Accessed on July 10, 2020)

8. Homicide rate per year per 100,000 inhabitants in various countries. 2020 [Internet] Available at: www.nationmaster.com/ country-info/ stats/crime/murder-rate (Accessed July 15, 2020)

9. Statistics in Category: Crime. 2020, [Internet] Available at: https://www.nationmaster.com/country-info/stats/crime (Accessed on July 15,2020)

10. Omalu BI, DeKosky ST, Minster RL, Kamboh MI, Hamilton RL, Wecht $\mathrm{CH}$. Chronic traumatic encephalopathy in a National Football League player. Neuros 2005; 57(1): 128-134.
11. Syrjänen SM, Sainio P. Forensic dentistry-recent development towards an independent discipline in modern dentistry. Proceedings of the Finnish Dental Society. Suomen Hammasl Toimit 1990; 86(3-4): 157-170.

12. Prabhu RV, Dinkar AD, Prabhu VD, Rao PK. Chei-loscopy: Revisited. J Foren Dent Sci 2012; 4(1): 47-52.

13. Kasprzak J. Possibilities of cheiloscopy. Foren Sci Int 1990; 46(1): 145-151.

14. Nagarajappa R, Mehta M, Shukla N, Tuteja JS. Awareness of forensic odontology among dental practitioners in Kanpur city, India: a KAP study. J Dental Res 2014; 1(1): 6-12.

15. Ali A, Sardar K, Nasir S, Waqar S. Knowledge, attitude and practice of forensic odontology among graduates and post graduate students at Dow University of Health Sciences (DUHS); J Pak Dent Assoc 2018; 25(3): 110-114.

16. Chandra Shekar B, Reddy C. Role of dentist in person identification. Ind J Dent Res 2009; 20(3): 356-360.

17. Akram S, Arif Z, Khan S, Tauheed S. Knowledge, awareness and practice of forensic odontology among dental practitioners in Karachi, Pakistan. Pak J Med Dent 2019; 8(01): 78-83.

18. Zeeshan M, Khalid; B, Siddiqi M, Jabeen N, Israr M. Awareness and compliance about forensic dentistry among dental professionals of twin cities of Rawalpindi-Islamabad: A questionnaire based study. Pak Oral Dent J 2014; 34(2): 277-282.

19. Babar MG, Iqbal S. Essential guidelines for forensic dentistry. Pak Oral Dent J 2007; 27(1): 79-84.

20. Alamad S, McCullough M, Graham J, Clement J, Hill A Craniofacial identification by computer-mediated super imposition. J Forensic Odontostomatol 2006; 24(2): 47-52. 